\title{
Silence and Absence in the Political Discourse on Section 28 and Children's Literature in the United Kingdom
}

\begin{abstract}
This article considers the previously unexamined political uses of children's literature in the 1986-1988 British Parliamentary debates of the legislation that became Section 28 of the Local Government Act 1988. This law, now repealed, prohibited the "promotion" of homosexuality and "pretended" same-sex family relationships by local authorities in the United Kingdom. The effect of the legislation was a widespread silencing of LGBT+ people in institutions across the nation. But while much has been written about those effects and on Section 28 generally over the past 30 years, there has been less sustained attention, within the context of the debates, given to those children's books and how they were used by politicians to justify the law. With a particular focus on two of the most prominent texts in the Parliamentary debates - David Rees' teen novel, The Milkman's on his Way (1982), and Susanne Bösche's picturebook, Mette bor hos Morten og Erik, published in English as Jenny Lives with Eric and Martin (1981/1983) - this article examines the political uses and constructions of children's texts and argues that silence and absence were a key discursive strategy deployed by supporters of the law.
\end{abstract}

Keywords: sexuality, British Parliament, discourse analysis, political ideology, Hansard, David Rees, Susanne Bösche

(C2020 J. Simpson. This is an Open Access article distributed under the terms of the Creative Commons Attribution-Noncommercial 3.0 Unported License (http://creativecommons.org/ licenses/by-nc/3.0/), permitting all non-commercial use, distribution, and reproduction in any medium, provided the original work is properly cited.

Citation: Barnboken - tidskrift för barnlitteraturforskning/Journal of Children's Literature Research, Vol. 43, 2020 http:/ /dx.doi.org/10.14811/clr.v43.515 
This article examines silence and absence in the political discourse on children's literature during the British Parliamentary debates on the prohibition of the "promotion" of homosexuality and "pretended" same-sex family relationships by local authorities. ${ }^{1}$ Described by Jeffrey Weeks as "the key legislative move in the 1980s" for lesbian and gay history (Coming Out 238), this prohibition was enacted as Section 28 of the Local Government Act 1988. While much has been written about this law over the past 30 years, the central role that children's literature played has gone unexamined. There has been little attention given in particular to the discursive treatment and political construction of children's literature, and to silence and absence as a discursive strategy among supporters of the law. The following discussion addresses the absence of such research by examining Parliament's political uses of children's literature. It argues that, while many reasons and justifications for Section 28 were proffered by politicians, those reasons, when considered alone, tell an incomplete story, as the law was a product not only of those vocalised reasons, but also of what was not included or considered. The article further reveals how silence, and thus power, operated in the debates, recalling Ellen K. Feder's argument that power operates in discourse through "certain silences or interrogatory gaps" (94). Adopting Taiwo Oluwaseun Ehineni's definition, "silence" is used here to refer to the absence, omission, or suppression of meaningful information (288). Silence and absence operated primarily through omissions by politicians of what certain children's texts actually contained, and further manifested as the absence of evidence supporting politicians' claims about what texts young people could access through schools and libraries (that is, the texts actually being "promoted" to young readers, if mere access to such literature can be deemed to rise to the level of "promotion" - a question never resolved in the debates). Examining the debates in this context reveals them as particularly significant not only for what they say, but also for what they do not say, about children's literature.

Children's literature played a key role in the Parliamentary debates from the start. Jenny Lives with Eric and Martin, the 1983 English version of the Danish picturebook Mette bor hos Morten og Erik (1981) by Susanne Bösche, with photographs by Andreas Hansen, is often cited as sparking the legislation (e.g. Colvin and Hawksley 2; Elliott and Humphries 227). Published by the Gay Men's Press, the book depicts a young girl living with her father and his male partner, with black-and-white photos showing their various activities together, such as baking a birthday cake. In 1986, with titles such as "Vile Book 
in School" and "Scandal of Gay Porn Books Read in Schools," several tabloids claimed that Bösche's book was being made available to children in London schools (Jeffery-Poulter 207). However, only a single copy was kept by the local London education authority, and it was in a "teachers' resource centre" (that is, not in a school) with controlled access (Colvin and Hawksley 2; see also Wright and Reinhold 88; and Elliott and Humphries), Nevertheless, the claim that local councils were promoting homosexuality to children at taxpayer expense continued to circulate. Throughout the debates, lawmakers subsequently cited Bösche's picturebook and several other texts to justify Section 28, such as Positive Images, the 1986 resources guide about homosexuality, including lesbian and gay literature, for teachers and librarians; Young, Gay and Proud! (Alyson), a 1980 book written by teens for teens; and Joani Blank's 1981 workbook, The Playbook for Kids about Sex for younger readers. This article discusses two texts in particular, Jenny Lives with Eric and Martin and David Rees' teen novel, The Milkman's on his Way (1982). This focus is for two reasons (in addition to the limited space available in a single journal article): (1) the books featured prominently amongst justifications lawmakers offered for Section 28; accordingly, (2) both serve as a case in point for the discursive treatment of children's literature and how silence and absence were deployed in the Parliamentary debates.

\section{Sexual Politics and the New Right: The Socio-Historical Context of Section 28}

The 1980s saw the beginning of the AIDS crisis (see Hallsor; and Gallo) - referred to in its early days as gay-related immune deficiency, or GRID - and growing fears of its spread among the so-called "general population" (Berridge 180; Weeks, Coming Out 246). A newspaper poll taken in 1986, for example, found that $56 \%$ of respondents believed people with AIDS should be sterilized, while $24.5 \%$ believed they should be isolated in camps (Haste 276). Meanwhile, the New Right political movement continued to grow with deep political opposition to homosexuality (Smith; see also Berridge; Wise; Epstein). Dame Jill Knight, then a Conservative member of the House of Commons, claimed, for example, that what children were learning in schools "would undoubtedly lead to a great spread of AIDS" (HC Deb., 8 May 1987 c998²). Similarly, then Prime Minister Margaret Thatcher claimed that children were being taught not "to respect traditional moral values" but "that they have an inalienable right to be gay" (Weeks, Coming Out 239). Such opposition was no mere rhet- 
oric. The government conducted, for example, a 1984 raid on Gay's the Word Bookshop in London under the charge (later withdrawn) of importing obscene literature (McManus 103). The New Right thus further stigmatised an already-marginalised population, feeding into and being fed by wider public prejudices and hostility.

But there was also an increasing number of community support organisations, including the Campaign for Homosexual Equality, London's Lesbian and Gay Employment Rights Group, and the Gay London Police Monitoring Group (Clews 31). This support included several publications, some of which were backed by local authorities, aimed at supporting young lesbian and gay people. For example, the London Gay Teenage Group published Lorraine Trenchard and Hugh Warren's Something to Tell You: The Experiences and Needs of Young Lesbians and Gay Men in London (1984), about the experiences of lesbian and gay students. And the City of Leicester Teachers' Association published Outlaws in the Classroom: Lesbians and Gays in the School System (1987), which offered support for teachers who were, and/or had students who were, gay or lesbian. There was thus growing support for young people experiencing or questioning non-heteronormative desires - described by Weeks as "a new assertion of community rights" (Against Nature 105). Section 28 was a countermeasure preventing local authorities from giving assistance (financial or otherwise) to the "promotion" of homosexuality as an acceptable family relationship.

As others have pointed out (e.g. Greenland and Nunney), Section 28 law was widely misunderstood as a prohibition that applied directly to schools and teachers. Technically, it was a regulation of local authorities (Thorp and Allen 13; see also Epstein 2), but its confusing language and the lack of government guidelines led to the common misunderstanding, which still persists today, that the law's scope included schools and individual school employees, such as teachers and librarians. The result was a de facto prohibition and, as Weeks notes, a "return to the closet" (Coming Out 242): school libraries refused to offer literature or films portraying lesbian or gay identities, and school staff effectively self-censored (Epstein). Even today, the now-repealed law still has real impact: Catherine Lee found that teachers who grew up under Section 28 are now "less open about their sexuality, unlikely to engage in the school community with their partner and more likely to see their teacher and sexual identities as incompatible" (2). In other words, while the law was technically narrow in scope, it had an outsized effect, silencing LGBT+ people - their voices and experiences, indeed their very existence - in institutions across the United Kingdom. 
But while much has been written about those effects, less attention has been given to the key role of children's literature in the debates. To examine that role and understand the political constructions and uses of that literature, the data for this article is comprised of the Hansard transcripts of the 1986-1988 debates of the Bills that led to Section 28, beginning with the legislation's first iteration by Lord Halsbury in 1986, and studied through Foucauldian discourse analysis, as informed by Jean Carabine (2001). An iterative process identified themes and the discursive strategies used by politicians. The findings demonstrate that the political discourses of "the child" were actually concerned with multiple discourses (for example, discourses of sexuality, morality, education, and children's literature). The most striking findings have been that politicians apparently believed all children to be latently homosexual, and that Section 28 was an attempt to suppress literature that could activate that latency. Because these findings (hopefully to be published in future) are beyond the space of a single article, the focus here is on one specific discursive strategy - silence and absence - and the political beliefs about children's literature as revealed by two texts in particular: Jenny Lives with Eric and Martin and The Milkman's on his Way.

\section{The Political Silencing of Jenny Lives with Eric and Martin and The Milkman's on his Way}

Silence and absence emerge as a political strategy primarily through misrepresentations of the content of certain children's texts (often coupled with omission of the actual content altogether) and the absence of evidence supporting many claims about the texts (and, indeed, omission of the actual content of the books is itself a suppression of textual evidence). Consider Dame Knight's characterisation of Jenny Lives with Eric and Martin. The book contains rather mundane black-and-white images and depictions of everyday activities, such as grocery shopping and baking a cake. Yet of all those images, Dame Knight and others zeroed in on just one: Jenny sitting in bed next to Eric and Martin, both of whom appear to be without clothes but are covered by bed sheets. Dame Knight said that photo " pictures a little girl of about six in bed with her father and his lover, both of whom are naked [...] It is terrifying to me that local councils have been promoting that kind of stuff" (HC Deb., 8 May 1987 c997-998). The belief here is that, because the two men are naked, they must be abusing the child. That link between nakedness and violence is implicit in the characterisation of the image as "terrifying." It suggests a fear not 
just of nakedness but of homosexual nakedness, displacing abuse onto that nakedness and recalling Gayle S. Rubin's argument that "[d]isputes over sexual behaviour often become the vehicles for displacing social anxieties, and discharging their attendant emotional intensity" (143). What was perhaps ultimately at stake was Bösche's portrayal of same-sex partners with a child as a family - the very sort of "pretend" relationship Section 28 was intended to suppress. The book's images resisted assimilationist or normative constraints of the traditional, "acceptable" family life constituted in and by the debates. Facing this threat, its images were characterised as terrifying and its content as abusive.

The sexualisation of the image also reflected mistranslation of cultural representations. Jenny Lives with Eric and Martin was originally published in Denmark, a country noted for its lack of inhibition to nakedness. "Danes, children as well as adults, have, for example, collective shower-rooms that they use after exercising [and] are often naked on the beaches" (Mirdal 403). Their "cultural liberation can be traced back to [...] near the end of the nineteenth century" (Bonde, cited in Frydendal and Friis Thing 162). While the British Parliament enacted Section 28, Denmark banned discrimination on the grounds of sexual orientation in 1987 and 1996 and introduced registered same-sex partnerships in 1989 (Edelberg 57-58). These cultural differences clearly did not translate to the British context in which Dame Knight found herself "terrified." Her characterisation of those differences was, in effect, a silencing of the ways of being and existing in social life different to the United Kingdom's cultural hegemony.

The second example of misrepresentation involved The Milkman's on his Way. Dame Knight and Conservative MP Michael Howard both argued that Rees' novel "glorifies" homosexuality (HC Deb., 8 May 1987 c997; SC A, 8 December 1987 c1209). While the novel does have a positive ending, it is a stretch of the imagination to describe it as glorifying homosexuality. In the first chapter alone, Ewan, the main character, believes he will bring his mother "more sorrow than joy"(Rees, Milkman's 8), and that being gay is "awful" (11), "pathetic" (11), "the end of the world" (12), and "repellent" (12). He experiences many hardships as he comes to terms with his sexuality: his mother at first believes him to be sick and wants him to see a doctor; his best friend punches him, drawing blood, then refuses to talk to him; and he witnesses another gay employee be repeatedly and violently assaulted and battered at work, and is then fired for trying to protect that employee. While Ewan's relationships with his family 
and friend are later repaired, the portrayals of these experiences are examples not of some glorious realm of homosexuality but the perseverance of one individual against physical danger, prejudice, and discrimination.

Given the actual content of the novel, it is perhaps unsurprising that there was an outright refusal by lawmakers to support their characterisations with textual evidence. Baroness Caroline Cox, for example, told the House of Lords that to quote from The Milkman's on his Way would shock the Peers (HL Deb., 18 December 1986 c321). In the House of Commons, Dame Knight similarly objected to the novel's "explicit terms," calling it "a pile of filth" (HC Deb., 8 May 1987 c998) and refusing to quote or read it aloud. The staunch refusal to discuss the book's actual content is rather ironic given that Parliament, a clearly adult audience of lawmakers, had assembled precisely to discuss such content and determine whether it required government intervention - a significant purpose that would seem to require close examination by lawmakers. Furthermore, this political treatment reinforced a view of same-sex sexual activity, of any book portraying such activity, and of those who experience the same or similar desires as Ewan's, as perverted and outside the "norm" of what was acceptable. It was a discursive denigration of nonheteronormative desires and reified a hierarchy of intimate relationships.

These circumstances call for closer examination of Rees' novel to understand these political characterisations of it and undo, at least to some extent, its discursive political silencing. Published by the Gay Men's Press (Britain's pioneering publisher of literature for the gay community, first established in 1979), the novel is set in the small town of Bude and follows the life of a gay teen named Ewan, a surfer who at first has difficulty resolving his lack of interest in girls. He eventually meets Paul, a teacher from London vacationing with a group of friends, all of whom are also gay. They spend a week together intimately and socially, and it is probably these particular passages that offended Baroness Cox and Dame Knight. There are, specifically, three scenes to which they were likely objecting.

The first scene is between Ewan and his best friend, Leslie, as they wrestle in Ewan's bedroom:

Our legs touched. Sweat. Then the most extraordinary, unlooked for, incredible thing happened. His hand was inside my shorts [...] I tugged at his shorts. I wanted to see. "What the hell do you think you're doing?" he asked. But changed his mind: they were obviously 
a handicap. He shut his eyes. I did not, amazed at what I saw. I hadn't realised how much the size of an erect cock differed from one person to another. Noticing other boys, limp in the changing room at school, had told me mine was much the same as other people's. But Leslie's was a prodigy. Would a girl be able to cope with such a weapon?

I wanted to touch him, caress him, wrap myself round him, kiss him all over. I didn't, of course. He was doubtless pretending that my hand was Linda's or Adrienne's or whoever the girl of the moment was, and I... I only saw him. The climax was the most ecstatic few seconds I had ever experienced. (Rees, Milkman's 20)

Leslie then gets dressed and leaves, and Ewan thinks about being with him again:

I'd not ask, not even suggest or hint such a thing. It would have to happen exactly as it had done just now, spontaneously, he starting it. Any move on my part and I would be exposed for what I was, with all the dire and dreadful consequence such knowledge in the hands of others would bring down on me.

Sperm on my skin, his mixed with mine. I touched it, then licked my finger. I was still perpendicular, firm as a rock; a situation I could do something about, and I did, reliving the experience in my imagination. (Rees, Milkman's 21)

While these passages are explicit, Baroness Cox and Dame Knight characterised them as "filth," conflating Ewan's self-discovery with pornography and furthering the ideological belief that same-sex attraction corrupts the young.

In the second scene, Ewan and his new friend, Paul, are naked on a beach:

[Paul] was touching my skin, caressing me, sucking my cock, arousing me so much that I felt there could be no stopping now even if coach-loads of people suddenly appeared on top of the cliffs [...] This was making love: so much feeling passed between us, so much gentleness. We came at exactly the same moment, in each other's hands. (Rees, Milkman's 55)

This scene portrays Ewan's continued journey of discovering who he is and what it means to experience same-sex attraction. While his first experience with Leslie was focused on physical pleasure, this scene shows the attraction as something more - a conduit for love, for both physical and emotional closeness. 
In the third scene, Ewan is again with Paul:

At first I was frightened; it would be painful, I thought. Did I really feel an urge for this? It was, perhaps, a denial of my maleness? I should penetrate: that was what it was for. Wasn't it? Everybody said so. Into Paul? The idea was ridiculous. I wanted him inside me; I wanted to be fucked. Only that would give me absolute satisfaction, emotionally.

"If it hurts," [Paul] said, kissing me, stroking me with his fingers, "I won't do it. I promise. This will make it easier."

"What?"

"K.Y. A lubricant."

Pain, yes, quite severe - he wasn't small - but only a bit (I would get used to that in time; indeed soon there was never any discomfort), it was the most natural, normal and utterly beautiful experience. His hand, still slippery with K.Y. on my cock, a sensation more superb than any I had ever felt, then orgasm so perfect I thought I was changed from a body into pure dazzling light. And he, coming, the spurt and gasp of him inside me: oh yes; this is what life is for, Ewan: for this I was made.

Kisses, gentle hands touching skin. Drifting towards sleep. (Rees, Milkman's 58)

As with the scene above, this passage, while explicit, is a positive portrayal of same-sex attraction, showing it as pleasurable rather than detrimental to young people. And it is important to note that this and the other scenes combined take up roughly a page and a half of the entire 118-page novel. Thus, even if these passages are nothing more than gratuitous (and I disagree that they are so), they are clearly not central to the novel, which is really about Ewan's changing relationships and wider journey to adulthood and self-acceptance, like many other teen novels.

Yet the merits of the work as a whole were never debated by Parliament, who instead seemingly judged the novel by the one-word rhetoric used to describe it ("filth") and the righteous indignation evoked by that characterisation. Indeed, the only substantive reference to the book's actual content beyond what can be read on the back cover was when Dame Knight referenced the ages of two characters - "a 16-year-old boy and his adult male homosexual lover" (HC Deb., 8 May 1987 c997). Yet even that language - "boy" and "adult male" - inaccurately frames the sex as abusive and predatory rather than consensual and pleasurable (and further misrepresents Ewan's age, as he was 17, not 16). Furthermore, Baroness Cox and 
Dame Knight refused to even quote any part of the text, even though Parliament had assembled specifically to consider these matters. By ignoring the book's content, Dame Knight could object based on her perception alone that the "book glorifies homosexuality and encourages youngsters to believe that it is better than any other sexual way of life" (HC Deb., 8 May 1987 c997). No other evidence, apparently, was required.

\section{A Double Standard: The Implicit Approval of Explicit Heterosexual Content}

This brings us to another notable silencing or absence in the debates, which was any discussion of children's books and resources with explicit heterosexual content. There was no analysis or consideration of heterosexual literature, despite the fact that many such novels for young people were more explicit than The Milkman's on his Way. One rather well-known example of such a text is Judy Blume's 1975 book, Forever, which includes several scenes in which teenagers are stroking breasts, spreading legs, fondling genitals, having orgasms, and attempting sex (in different positions), sometimes achieving penetration, sometimes not. Consider one such passage:

This time I tried to relax and think of nothing - nothing but how my body felt - and then [he] was brushing against me and I whispered, "Are you in... are we doing it yet?"

"Not yet," Michael said, pushing harder. "I don't want to hurt you."

"Don't worry... just do it!"

"I'm trying, Kath... but it's very tight in there."

"What should I do?"

"Can you spread your legs some more... and maybe raise them a little?"

"Like this?"

"That's better... much better."

I could feel him halfway inside me and then Michael whispered, "Kath..."

"What?"

"I think I'm going to come again."

I felt a big thrust, followed by a quick sharp pain that made my suck in my breath. (Blume 88-89)

Similar scenes span two or more pages, lengthy and numerous passages that stand in stark contrast to the three short scenes in The Milk- 
man's on his Way. The passages in Blume's novel also tended to depict sex as painful, in marked contrast to the way Rees centred pleasure in his portrayals of sex. Yet there was no Parliamentary discussion of this or any other novel with sexually explicit but heterosexual content. Only texts portraying homosexuality were subjected to Parliament's morality discourse. This double standard is striking given that Parliament believed literature was so powerful it could forever "pervert" children (that is, activate their latent homosexuality). Further, it suggests that the effects of heterosexual literature on young minds were irrelevant to Parliament, a position highlighted by Simon Hughes, an MP who would later become Deputy Leader of the Liberal Democrats and told the House of Commons:

If the clause's aim is to protect the young, why are we not doing something about soft porn magazines, which are on sale in newsagents? Why are we not doing something about the matter raised by the hon. Member for Birmingham, Ladywood (Ms. Short) only last year - page 3 pictures in the popular newspapers? If we are trying not to promote different forms of sexuality, why do we not deal with television advertising, which often tries to sell products merely by appealing to people's sexual nature and motives? Why do the Government suddenly select this target, rather than another? (HC Deb., 15 December 1987 c993)

The omission of porn magazines, televisions ads, and mainstream, popular teen novels demonstrates the operation of heteronormativity as the standard for evaluating what literature young minds should unproblematically be able to access. Perhaps Parliament was unconcerned about children's exposure to these texts and products because such exposure could only encourage heterosexuality (and thus suppress the latent homosexuality lawmakers apparently believed was present in every child, which I will demonstrate in future work). In other words, because these reading materials support dominant norms of sexuality and gender, they were not a rejection of heteronormative values and therefore were apparently unproblematic, resulting in discursive discrimination as to what sort of literary portrayals would require government debate and intervention (portrayals of non-heterosexual desire and relationships) and which would not (portrayals of heteronormative desires and relationships).

Setting aside the content of Rees' work and the other children's texts at issue, lawmakers also misrepresented the extent to which the texts were being made available to, and read by, young people, with a notable absence of any evidence for some of the claims. Alt- 
hough Baroness Cox argued that, because of the novel's explicitness, it was "totally inappropriate for use in schools" (HL Deb., 11 January 1988 c1013), the record I have been able to obtain reflects no confirmation in Parliament that the book was ever actually available in schools - an evidentiary silence. When Conservative MP Michael Howard was asked to produce records substantiating his claims that local authorities were giving non-heterosexual reading material to children, and that the London borough of Haringey had published an approved reading list recommending Young, Gay and Proud! "as suitable reading for children aged 13 upwards" (SC A, 8 December 1987 c1209), he told the committee that "[t]ime has not permitted me to distribute copies of my evidence" (SC A, 8 December 1987 c1209). Similarly, Conservative MP David Wilshire, who introduced the Bill that became Section 28, claimed that Young, Gay and Proud! was "in the children's section of the Haringey library and [...] taken out by a 15-year-old" (SC A, 8 December 1987 c1223). MP Bernie Grant, however, was adamant that the book "was certainly not in the Haringey library" and suggested that it had actually been planted there by "a member of the infamous parents [sic] rights group in Haringey" who then asked one of their children to take out the book (SC A, 8 December 1987 c1223). Their evidence was never produced or made part of the record (as far as I have been able to ascertain ${ }^{3}$ ), which suggests that it was never considered by Parliament.

Consider also Labour MP Paul Flynn's challenge to Howard to give one single example of literature with non-heterosexual content being made available to children outside of London (SC A, 8 December 1987 c1209). Howard responded: "I dare say that examples could be found from elsewhere. The problems are not mythological. I have provided chapter-and-verse examples" (SC A, 8 December 1987 c1210). Of course, arguing that other examples could be found is not quite the same as actually finding and producing those examples. The absence of evidence in this and the above examples suggests that lawmakers were uninformed not only about the content of the relevant texts, but about the very provision of those texts and what young people were actually reading.

\section{Judging a Book by Its Cover: Concluding Thoughts on the Political Silencing of Children's Literature}

As we have seen, the political use of silence and absence operated through obfuscation or suppression of the nature and content of certain children's texts and, further, by the absence of evidence 
supporting some claims about what texts children could and were accessing. Section 28 came to pass, at least in part, specifically because of what was not included in that political discourse. Perhaps the most significant political silencing of all was a failure to consider the ways in which books can help support, and serve as valuable sources of information for, young people and adults who work with young people. Consider Rees, who himself came out as gay at the age of 37, who called for

granting to the child or the teenager time and space to make up his own mind about who he is and what he needs to be and to do, a time and a space either denied to me, or which I denied myself, and which I had to fight for in adulthood. (Rees, “On Katherine Paterson” 169)

These words capture what was largely absent from the discourse of Section 28 proponents: the recognition that young people need "time and space" to form their own identities in safe and supportive environments, and the ways in which that can be offered by literature.

Ultimately, the books by Rees, Bösche, and others opened up new possibilities - new ways of being - for young readers and resisted hegemonic forms of intimate relationships. The powerful resistance inherent in these texts is the public (that is, published and circulated) demonstration of alternative ways of being outside hegemonic norms - ways that lawmakers were forced to grapple with (as evidenced by Section 28, and the raid on Gay's the Word Bookshop), revealing the power of children's literature to engage those hegemonic forces, require a response, and shape the political discourse on children and family life. Further power can be seen in the fact that the discourses about such texts were, regardless of how homosexuality was characterised, speaking nevertheless about homosexuality. As Didier Eribon notes, "to speak about [homosexuals] was in some way to allow them to recognize themselves. It allowed them to move beyond the feeling they all must have had of being alone in the world" (150). This is the hope that children's literature offers.

As demonstrated, many lawmakers sought to prescribe exactly the kind of identity young people should be allowed to develop. The political discourse reinforced the "otherness" of, and stigmatisation against, non-heteronormative desires and relationships and the literature that portrays them, all of which were constituted not only as corrupting but fatal to individuals and even society itself. These constructions privileged heterosexual, reproductive family life over "pretended" non-heteronormative relationships, reifying 
and legitimating that hierarchy of intimate relationship structures that persists today. These were the norms by which children's literature was evaluated by lawmakers - politicians who were clearly amongst what Teun A. van Dijk has called the "ideological leaders of society" (107) - to be moral or immoral, acceptable or unacceptable, dangerous or not dangerous. These political and ideological leaders argued, through strategic silencing, that any literature with nonheterosexual content should be feared, reviled, and rejected regardless of its actual content and availability to young readers.

Biographical information: A former lawyer, Joshua Simpson is a writer, educator, and PhD researcher based at the University of Strathclyde in Scotland. His research is an interdisciplinary study of Section 28's legacy. He is the Executive Editor of International Research in Children's Literature and co-founder of Researchers Exploring Inclusive Youth Literature.

\section{Works Cited}

Alyson, Sasha, editor. Young, Gay and Proud! Boston, Alyson Publications, 1980.

Berridge, Virginia. "Aids, the Media and Health Policy." Health Education Journal, vol. 50, no. 4, 1991, pp. 179-85, doi.org/10.1177/0017 $\underline{89699105000407 .}$.

Blank, Joani. The Playbook for Kids about Sex. San Francisco, Yes Press, 1981.

Blume, Judy. Forever. London, Macmillan Children's Books, 1975.

Carabine, Jean. “Unmarried Motherhood 1830-1990: A Genealogical Analysis." Discourse as Data: A Guide for Analysis, edited by Margaret Wetherell et al., London, Sage Publications, 2001.

Clews, Colin. Gay in the 80s: From Fighting for Our Rights to Fighting for Our Lives. Leicester, Troubador Publishing, 2017.

Colvin, Madeleine, and Jane Hawksley. Section 28: A Practical Guide to the Law and Its Implications. London, National Council for Civil Liberties, 1989.

Edelberg, Peter. "The Long Sexual Revolution: The Police and the New Gay Man." Sexual Revolutions, edited by Gert Hekma and Alain Giami, New York, Palgrave Macmillan, 2014, pp. 46-59. 
Elliott, Sue, and Steve Humphries. Not Guilty: Queer Stories from a Century of Discrimination. London, Biteback Publishing, 2017.

Epstein, Debbie. "Introduction: Lesbian and Gay Equality in Education - Problems and Possibilities." Challenging Lesbian and Gay Inequalities in Education, edited by Debbie Epstein, Buckingham, Open University Press, 1994, pp. 1-24.

Eribon, Didier. Insult and the Making of the Gay Self. Durham and London, Duke University Press, 2004.

Feder, Ellen K. Family Bonds: Genealogies of Race and Gender. New York, Oxford University Press, 2007.

Frydendal, Stine, and Lone Friis Thing. "A Shameful Affair? A Figurational Study of the Change Room and Showering Culture Connected to Physical Education in Danish Upper Secondary Schools." Sport, Education and Society, vol. 25, no. 2, 2019, pp. 161-172, doi.org/ $\underline{10.1080 / 13573322.2018 .1564654 .}$.

Gallo, Robert C. "A Reflection on HIV/ AIDSResearch after 25 Years." Retrovirology, vol. 3, no. 72, 2006, doi.org/10.1186/1742-4690-3-72.

Greenland, Katy, and Rosalind Nunney. "The Repeal of Section 28: It Ain't Over 'til It's Over." Pastoral Care in Education, vol. 26, no. 4, 2008, pp. 243-251, doi.org/10.1080/02643940802472171.

Hallsor, Samuel. "A Comparison of the Early Responses to AIDS in the UK and the US." Res Medica, vol. 24, no. 1, 2017, pp. 57-64, doi. org/10.2218/resmedica.v24i1.1558.

Haste, Cate. Rules of Desire: Sex in Britain, World War I to the Present. London, Pimlico, 1994.

HC Deb. 8 May 1987 Debate (Vol. 115, cc997-1014), api.parliament.uk/historic-hansard/commons/1987/may/08/amendment-of-local-government-act-1986. Accessed 20 August 2020.

--- 15 December 1987 Debate (Vol. 124, cc987-1038), https://api.parliament.uk/historic-hansard/commons/1987/dec/15/prohibition-on-promoting-homosexuality. Accessed 20 August 2020.

HL Deb. 18 December 1986 Debate (Vol. 483 cc310-338), api.parliament.uk/historic-hansard/lords/1986/dec/18/local-government-act1986-amendment-bill. Accessed 20 August 2020.

---. 11 January 1988 Debate (Vol. 491, cc947-1033), api.parliament.uk/ historic-hansard/lords/1988/jan/11/local-government-bill. Accessed 20 August 2020. 
Jeffery-Poulter, Stephen. Peers, Queers, and Commons: the Struggle for Gay Law Reform from 1950 to the Present. London, Routledge, 1991.

Lee, Catherine. "Fifteen Years on: The Legacy of Section 28 for LGBT+ Teachers in English Schools." Sex Education, vol. 19, no. 6, March, 2019, pp. 675-690, doi.org/10.1080/14681811.2019.1585800.

McManus, Michael. Tory Pride and Prejudice. London, Biteback Publishing, 2011.

Mirdal, Gretty M. "Changing Idioms of Shame: Expressions of Disgrace and Dishonour in the Narratives of Turkish Women Living in Denmark." Culture \& Psychology, vol. 12, no. 4, 2006, pp. 394-414, doi. org/10.1177/1354067X06067142.

Oluwaseun Ehineni, Taiwo. "A Discourse Analysis of Absence in Nigerian News Media." Exploring Silence and Absence in Discourse: Empirical Approaches, edited by Melani Schröter and Charlotte Taylor, Cham, Palgrave Macmillan, 2018, pp. 281-302.

Outlaws in the Classroom: Lesbians and Gays in the School System. Leicester, Leicester Teachers' Association (NUT), 1987.

Positive Images. London, Inner London Education Authority Learning Resources Branch, 1986.

Rees, David. The Milkman's on his Way. London, Gay Men's Press, 1982.

---. “On Katherine Paterson, Alexander Pope, Myself, and Some Others." Children's Literature in Education, vol. 14, 1983, pp. 160-170, doi. org/10.1007/BF01142203.

Rubin, Gayle S. "Thinking Sex: Notes for a Radical Theory of the Politics of Sexuality." Culture, Society and Sexuality: A Reader, edited by Richard Guy Parker \& Peter Aggleton, London, UCL Press, 1999, pp. 143-179.

SC A. Standing Committee A: Local Government Bill 8 December 1987. Her Majesty's Stationery Office, 1987.

Smith, Anna Marie. “The Imaginary Inclusion of the Assimilable 'Good Homosexual': The British New Right's Representations of Sexuality and Race." Diacritics, vol. 24, no. 2/3, 1994, pp. 58-70, doi. org/10.2307/465164.

Thorp, Arabella, and Gillian Allen. "The Local Government Bill [HL]: The 'Section 28' Debate." House of Commons Library, 2000, researchbriefings.files.parliament.uk/documents/RP00-47/RP00-47.pdf. Accessed 20 August 2020. 
Trenchard, Lorraine, and Hugh Warren. Something to Tell You: The Experiences and Needs of Young Lesbians and Gay Men in London. London, London Gay Teenage Group, 1984.

van Dijk, Teun A. Discourse and Power. New York, Palgrave Macmillan, 2008.

Weeks, Jeffrey. Against Nature: Essays on History, Sexuality and Identity. London, Rivers Oram Press, 1991.

---. Coming Out: The Emergence of LGBT Identities in Britain from the 19th Century to the Present. 3rd ed., London, Quartet Books, 2016.

Wise, Sue. "'New Right' or 'Backlash'? Section 28, Moral Panic and 'Promoting Homosexuality'." Sociological Research Online, vol. 5, no. 1, 2000, pp. 148-157, doi.org/10.5153/sro.452.

Wright, Susan, and Sue Reinhold. “'Studying Through': A Strategy for Studying Political Transformation: Or Sex, Lies and British Politics." Policy Worlds: Anthropology and the Analysis of Contemporary Power, edited by Cris Shore et al., New York, Berghahn Books, 2011, pp. 86-104.

\section{Notes}

1 I am indebted to Drs Ian Rivers and Vivienne Smith, without whom I would not have embarked on the doctoral research underlying this article, and all who have mentored me along that journey; the journal's editors and the anonymous referees, who helped shape the article; and the International Research Society for Children's Literature for the travel grant to present an early version of this paper at the 2019 Congress in Stockholm.

2 There is not a standardised, conventional citation format for the transcripts. The method adopted here uses "HL" to refer to the House of Lords, "HC" to the House of Commons in the first container, and "SC A" to refer to Standing Committee A. The second container is the date of the particular debate or committee, and the third is the column where the quote is located.

3 That these and other materials were not made part of the record was verified via email by Parliamentary Archives on 1 July 2019. 